\title{
Valoración hidro-ambiental y evaluación de coeficientes de agostadero mediante indicadores termo-pluviométricos
}

\section{Hydro-environmental assesment and grazing capacity valoration by thermo-pluviometrics indicators}

\author{
Leopoldo Villarruel-Sahagúna,b, Enrique Troyo-Diégueza, Oscar G. Gutiérrez-Ruachob, Alejandra \\ Nieto-Garibaya, Martín Esquedac, Peter Ffolliotd, Bernardo Murillo-Amadora, Gilberto Solís-Garzae
}

\begin{abstract}
RESUMEN
Para un manejo sustentable de una superficie de pastoreo, es necesario conocer la estrategia de la naturaleza para sostener el pastizal. En consecuencia, los esquemas de manejo deben fundamentarse en programas de caracterización ambiental y de seguimiento adecuados. Con la finalidad de contar con un instrumento de apoyo para el diagnóstico de agostaderos, se propone la aplicación del indicador de disponibilidad hidroambiental (IDHA), con escala de 0 a 10. Según la aplicación del IDHA en 36 localidades de Sonora, cinco de las mismas (13.9 \%) fluctuaron de 0 a 2.5 , por lo que sus pastizales son altamente vulnerables a las sequías, con pocas posibilidades de manejo; 20 (55.6 \%) oscilaron de 2.5 a 5, para las que se sugiere manejo con restricciones severas; once (30.5 \%) fluctuaron de 5 a 7.5 , para las que se propone manejo sostenible con rotaciones adecuadas y prevenciones durante la sequía, y ninguna de las localidades alcanzó valores de IDHA > 7.5, alto potencial de manejo sostenible mediante rotaciones adecuadas. Sin embargo las acciones para prevenir los efectos del sobrepastoreo, no siempre son suficientes para mitigar las consecuencias devastadoras de las sequías, las cuales son exacerbadas por el cambio climático.
\end{abstract}

PALABRAS CLAVE: Indice hidro-ambiental, Coeficiente de agostadero, Pastizales, Zonas áridas.

\begin{abstract}
For a sustainable management of grazing lands, is necessary to know the strategy of nature to sustain the grassland, in consequence, the management schemes must be based in programs related to an environmental characterization and adequate monitoring. With the aim to develop a tool to support the diagnosis of grasslands, we hereby propose the application of the Hydro-Environmental Availability Index (HEAI), with scale from 0 to 10. According to the application of HEAl in 36 localities of Sonora, Mexico, five of them (13.9\%) fluctuated from 0 to 2.5 , in consequence, their grasslands are highly vulnerable to drought, with very low possibilities for management. Twenty (55.6 \%) oscillated from 2.5 to 5, suggesting a management with severe restrictions. Eleven ( $30.5 \%$ ) fluctuated from 5 to 7.5 , proposing a sustainable management with adequate rotations and preventions during a drought, and none of localities reached values for HEAl > 7.5, high potential for sustainable management, with appropriate rotations. It must be considered that the actions to prevent the effects of overgrazing, not always are enough to mitigate the overwhelming consequences of droughts, which are exacerbated by climate change.
\end{abstract}

KEY WORDS: Hydro-environmental index, Sustainable management, Grazing lands, Arid zones.

Recibido el 25 de octubre de 2012. Aceptado el 17 de julio de 2013.

a Centro de Investigaciones Biológicas del Noroeste, SC (ClBNOR). Calle Instituto Politécnico Nacional 195, Colonia Playa Palo de Santa Rita Sur. 23096 La Paz, B.C.S. México. etroyo04@cibnor.mx. Correspondencia al segundo autor.

b Universidad Estatal de Sonora (UES). Hermosillo, Son. México,

c Centro de Investigación en Alimentación y Desarrollo, A.C. Hermosillo, Son. México.

d School of Natural Resources, University of Arizona, Tucson, AZ. USA.

e Universidad de Sonora. Unidad Regional Centro. UNISON. Hermosillo, Son. México.

Trabajo financiado por el Fondo Sectorial para la Investigación básica CONACyT-SEP, mediante el Proyecto "Determinación y construcción de indicadores de la huella hídrica y desertificación como consecuencia de la sobreexplotación agropecuaria y del cambio climático" (0134460). 


\section{INTRODUCCIÓN}

Los problemas derivados de la escasez de agua en zonas secas han demostrado la interdependencia del ecosistema con las comunidades que las habitan(1). La actividad ganadera en agostaderos de dichas zonas genera beneficios económico-productivos. Sin embargo, el manejo no planificado y la sobreexplotación de los recursos naturales han ocasionado erosión, agotamiento del agua y en algunos casos desertificación irreversible(2). La ordenación y rehabilitación de agostaderos y pastizales pueden concretarse de manera expedita en pequeñas cuencas unitarias, lo que facilita la integración de avances y resultados en el mosaico de una cuenca fluvial. La ordenación y manejo de cuencas implica la aplicación de estrategias a través de una coordinación interinstitucional en el sistemacuenca. Desde esta perspectiva, el manejo integrado y el ordenamiento ecológico son instrumentos útiles para enfrentar los problemas ambientales(3), por medio de la aplicación de políticas de desarrollo sostenible, privilegiando el valor estratégico del recurso hídrico(4). Un factor que merma el interés por proyectos de manejo de cuencas y agostaderos es la falta de resultados cuantitativos de los efectos benéficos(2), en virtud de que los proyectos tradicionales no valoran la condición inicial y final con indicadores que midan los resultados $(1,3)$.

Los ecosistemas de pastizales son rentables cuando su manejo considera la capacidad de carga natural del terreno, la cual se asocia a la fertilidad del suelo, precipitación y capacidad de retención de humedad(4). Según Hanselka y Kilgore(5), existen tres tipos de manejo para clasificar los sistemas de pastoreo: (a) método de pastoreo continuo, (b) sistemas de rotación diferida y (c) sistemas de corta duración.

Para el manejo sostenible de pastizales en zonas secas, el balance del agua debe analizarse en función de la disponibilidad hídrica resultante de la relación edafo-ambiental precipitaciónevaporación-retención de humedad(4). Dichos

\section{INTRODUCTION}

The problems arising from water shortages in dry areas have proven the interdependence of ecosystems with the communities that inhabit them(1). Grazing in rangelands of such areas generates benefits. However, unplanned management and overexploitation of natural resources have caused erosion, water depletion and in some cases irreversible desertification(2). The management and rehabilitation of rangelands and pastures can be realized expeditiously in small watersheds units, facilitating the integration of progress and results within the mosaic of a river basin. Management and watershed planning involves implementing strategies through inter-agency coordination in the System-Basin. From this perspective, integrated management and ecological system planning are useful instruments to address environmental problems(3), through the implementation of sustainable development policies, favoring the strategic value of water resources (4). A factor that affects the interest in management of watershed and rangeland projects is the lack of quantitative results of beneficial effects(2), because traditional projects do not consider the initial value and final condition with indicators that measure the results( 1,3$)$.

Grassland ecosystems are profitable when its management considers the carrying capacity of the land, which is associated with the soil fertility, rainfall and water holding capacity (4). According to Hanselka and Kilgore(5), there are three types of management to classify grazing systems: a) continuous grazing, b) systems of short duration and c) deferred rotation systems.

For sustainable rangelands management in dry areas, the water balance should be analyzed in terms on water availability, resulting from the relationship though edaphic-environmental moisture retention(4). These ecosystems face normal periods of water shortage, but also abnormal periods extended dramatically, becoming droughts. The effects of a drought and its impact depend on precipitation and the 
ecosistemas enfrentan periodos normales de déficit hídrico, pero también periodos anormales cuando se prolongan de manera extraordinaria, convirtiéndose en sequías. Los efectos de una sequía y su impacto dependen de las precipitaciones y de la oscilación térmica(6). En el sector pecuario, la escasez de pastos y la necesidad de forraje almacenado y piensos para mantener el ganado están provocando pérdidas económicas en el norte, centro-norte y noroeste del país(4). De acuerdo con la normatividad vigente en México, la Norma Oficial Mexicana NOM-020-RECNAT-2001(7) establece los procedimientos y lineamientos que deben observarse para la rehabilitación, mejoramiento y conservación de los terrenos forestales de pastoreo. En la norma citada, se indica que "la sequía puede considerarse como la disminución de las precipitaciones de una región respecto del valor normal en un periodo de tiempo, lo que crea una escasez de agua para los diferentes usos: de almacenamiento, agrícola, ganadero, municipal, industrial, etc. y para el ambiente: ríos, aguas subterráneas, humedad del suelo".

Según Crespo-Pichardo(8), la sequía es un fenómeno que comienza y termina de maneras no bien definidas, que su impacto es variado y que involucra diferentes variables, además de una deficiencia de precipitación. Para dicha condición se ha desarrollado más de una concepción. Entre los métodos reportados para la valoración de la sequía, el Índice de Severidad de Sequía de Palmer (ISSP)(9) se utiliza ampliamente en el mundo, toda vez que la investigación de sus aplicaciones para evaluar las sequías se realiza para diferentes condiciones ambientales; una de sus desventajas es el caudal de información que requiere, alrededor de 20 variables, por lo que su uso se dificulta cuando no se dispone de suficiente información climática.

\section{MATERIALES Y MÉTODOS}

Para la valoración del régimen pluviométrico de zonas con pastizales en el estado mexicano de thermal oscillation(6). In the livestock sector, pastures scarcity and the need for stored herbage for feeding livestock are causing economic losses in the North, North-Central and North-West Mexico(4). According with the current regulations in Mexico, Norma Oficial Mexicana (Official Mexican Norm) NOM-020-RECNAT$2001^{(7)}$ establishes the procedures and guidelines for the rehabilitation, improvement and conservation of grazing forestlands. This norm states that "Drought can be declared when the rainfall decrease in a region with respect to the normal value in a period of time, which creates a water shortage for various uses: storage, livestock, agricultural, municipal, industrial, etc. and the environment: rivers, groundwater, and soil moisture".

According to Crespo-Pichardo(8), drought is a phenomenon that begins and ends in ways not well defined, its impact is changeful and involves different variables, along with a deficiency of precipitation. More than one concept has been developed for this condition; the Palmer Drought Severity Index (9) is one the methods for drought assessment. It is widely used in the world, whenever the investigation of their applications to evaluate drought performs for different environmental conditions; one of its disadvantages is the information flow required, around 20 variables, so its use becomes difficult when there is insufficient climate information.

\section{MATERIALS AND METHODS}

To evaluate the rainfall pattern of grassland in the Mexican State of Sonora, the hydroenvironmental available index (HEAl), which is a modification of the De Martonne index, was applied(10). HEAl was used for comparative purposes through the analysis of hydro-climate sensitivity of 36 weather stations (locations) in Sonora, using data obtained from CLICOM(11), useful for making management grasslands decisions, and obtained by the equation (1):

$\mathrm{HEAl}=\mathrm{Ke}(12 \mathrm{pp}) /(\mathrm{t}+10)$

Where: HEAl is the hydro-environmental availability index, pp is the monthly precipitation 
Sonora, se aplicó el Índice de Disponibilidad Hidro-Ambiental (IDHA), el cual es una modificación del Índice de De Martonne(10). El IDHA fue aplicado con fines comparativos para el análisis de la sensibilidad hídrica de 36 estaciones meteorológicas (localidades) en Sonora (datos obtenidos de CLICOM(11)), de utilidad para la toma de decisiones relativas al manejo de pastizales, mediante la ecuación (1):

IDHA $=\mathrm{Ke}(12 \mathrm{pp}) /(\mathrm{t}+10)$

Donde: IDHA es el índice de disponibilidad hidroambiental, pp es la precipitación mensual en $\mathrm{mm}$, t es la temperatura media mensual $\left({ }^{\circ} \mathrm{C}\right)$ y Ke es un coeficiente adimensional de ajuste de escala, con valor de 0.306, el cual fue aplicado con la finalidad de alcanzar una mayor resolución que el índice de De Martonne. A su vez, para complementar el análisis de la condición hídrica, el Índice de Sequia HidroAmbiental (ISHA) se calculó mediante la siguiente expresión (Ecuación 2):

$$
\text { ISHA = Ka }- \text { IDHA }
$$

Donde: ISHA es el índice de sequía hidroambiental; $\mathrm{Ka}=10$, es una constante que define el límite superior de escala (ordenada al origen) y que determina el complemento escalar de ISHA e IDHA. in $\mathrm{mm}, \mathrm{t}$ is the monthly average temperature $\left({ }^{\circ} \mathrm{C}\right)$ and $\mathrm{Ke}$ is a non-dimensional scale coefficient, with value of 0.306 , which was applied in order to achieve a higher resolution than the De Martonne index. At the same time, to complement the analysis of water condition, the hydro-environmental drought index (HEDI) was calculated by the following expression (equation 2):

$\mathrm{HEDI}=\mathrm{Ka}-\mathrm{HEAI}$

Where $\mathrm{Ka}=10$; it is a constant that defines the upper limit of the scale (ranked at the origin) and that determines the range complement of HEDI and HEAI.

With HEAl and HEDI obtained, results were plot and locations classified by its rainfall, with pasture management-oriented application, according to the criteria listed in Table 1 . In order to corroborate the numerical functionality of HEAl and HEDI, regression and correlation analysis were applied with the rainfall generated by the information available from the 36 places evaluated. It also reviewed the stocking rates coefficients (SRC) (hectares per animal unit (AU) per year) determined by the "Technical Advisory Committee for the Regional Determination of

Cuadro 1. Criterios de aplicación e interpretación de los indicadores HEAI (índice de disponibilidad hidro-ambiental) y HEDI (índice de sequía hidro-ambiental)

Table 1. Application and interpretation criteria of indicators HEAI (hydro-environmental availability index and HEDI (hydro-environmental drought index)

\begin{tabular}{lcl}
\hline & Vulnerability & Management recomendations \\
\hline HEAI value & & \\
0 a 2.5 & Extreme & Total exclusion from grazing \\
2.5 a 5 & High & Severe managements restrictions, total exclusion during dry months \\
5 a 7.5 & Medium & Sustainable management with adequate rotations and preventions during drought \\
$>7.5$ & Low & High potential for sustainable management, use of adequate rotations \\
HEDI value & & Zone clasification \\
$<2.5$ & Non vulnerable & Humid \\
2.5 a 5 & Vulnerable & Semiarid (mediterranean type) \\
5 a 7.5 & Very vulnerable & Semi-desertic (arid) \\
7.5 a 10 & Greatly vulnerable & Desert (Hyperarid) \\
\hline
\end{tabular}


Una vez estimados IDHA e ISHA, se procedió a graficar los resultados obtenidos y a clasificar las localidades evaluadas por su pluviosidad, con aplicación orientada al manejo de pastizales, the Stocking Rates" (COTECOCA, acronym in Spanish) $(12,13)$ for each of the 36 meteorological stations, applied regression and correlation analysis between HEDI and SRC. The data

Cuadro 2. Estaciones meteorológicas del estado de Sonora analizadas con varios índices y sus coeficientes de agostadero (SRC) (ha/UA/año) $(10,11)$

Table 2. Weather stations in the State of Sonora analyzed with several indices, and their stocking rates coefficient (SRC) (ha/AU/yr) $(10,11)$

\begin{tabular}{|c|c|c|c|c|c|c|c|c|c|c|}
\hline & Station & Code station & $x$ & Y & $\mathrm{PP}, \mathrm{mm}$ anual & $\mathrm{T},{ }^{\circ} \mathrm{C}$ anual & MARI & HEAI & HEDI & $\begin{array}{c}\text { SRC } \\
\text { previous }\end{array}$ \\
\hline 1 & $4 p 6$ & 26292 & 575789 & 3032654 & 266.234 & 23.920 & 7.849 & 2.40 & 7.60 & 26 \\
\hline 2 & Álvaro Obregón & 26068 & 609988 & 3077227 & 411.917 & 25.870 & 11.484 & 3.51 & 6.49 & 33 \\
\hline 3 & Angostura & 26069 & 655258 & 3367728 & 393.473 & 20.863 & 12.749 & 3.90 & 6.10 & 19 \\
\hline 4 & Bacadehuachi & 26006 & 680419 & 3297906 & 481.066 & 20.610 & 15.716 & 4.81 & 5.19 & 25 \\
\hline 5 & Bacanuchi & 26007 & 573513 & 3383491 & 505.426 & 17.561 & 18.338 & 5.61 & 4.39 & 19 \\
\hline 6 & Banamichi & 26008 & 577161 & 3318875 & 454.618 & 21.804 & 14.295 & 4.37 & 5.63 & 27 \\
\hline 7 & Batacosa & 26009 & 658027 & 3044517 & 553.403 & 23.267 & 16.635 & 5.09 & 4.91 & 20 \\
\hline 8 & Bavispe & 26012 & 696777 & 3373945 & 405.979 & 19.519 & 13.753 & 4.21 & 5.79 & 19 \\
\hline 9 & Carbo & 26016 & 504839 & 3281676 & 405.979 & 20.822 & 13.172 & 4.03 & 5.97 & 22 \\
\hline 10 & Cuauhtémoc & 26092 & 452199 & 3414753 & 382.387 & 21.321 & 12.209 & 3.74 & 6.26 & 23 \\
\hline 11 & Cucurpe & 26025 & 528843 & 3353736 & 540.394 & 20.225 & 17.879 & 5.47 & 4.53 & 27 \\
\hline 12 & El Orégano & 26032 & 529159 & 3231855 & 421.223 & 23.809 & 12.459 & 3.81 & 6.19 & 24 \\
\hline 13 & Etchojoa & 26034 & 637376 & 2975943 & 320.703 & 23.338 & 9.620 & 2.94 & 7.06 & 19 \\
\hline 14 & Félix Gómez & 26035 & 454912 & 3300226 & 317.911 & 19.279 & 10.858 & 3.32 & 6.68 & 27 \\
\hline 15 & Hornos & 26043 & 608459 & 3064284 & 409.359 & 24.087 & 12.009 & 3.67 & 6.33 & 27 \\
\hline 16 & Imuris & 26045 & 512755 & 3405411 & 445.393 & 19.715 & 14.989 & 4.59 & 5.41 & 29 \\
\hline 17 & Mazatán & 26052 & 584420 & 3208119 & 524.525 & 20.785 & 17.038 & 5.21 & 4.79 & 24 \\
\hline 18 & Minas Nuevas & 26053 & 698370 & 2993381 & 757.160 & 23.020 & 22.930 & 7.02 & 2.98 & 22 \\
\hline 19 & Mulatos & 26055 & 719954 & 3169255 & 591.120 & 19.699 & 19.904 & 6.09 & 3.91 & 21 \\
\hline 20 & Naco & 26057 & 601500 & 3465007 & 343.621 & 17.299 & 12.587 & 3.85 & 6.15 & 19 \\
\hline 21 & Navojoa & 26061 & 655363 & 2994622 & 415.967 & 25.153 & 11.833 & 3.62 & 6.38 & 20 \\
\hline 22 & Onavas & 26265 & 645243 & 3147775 & 612.791 & 24.089 & 17.976 & 5.50 & 4.50 & 24 \\
\hline 23 & Pitiquito & 26093 & 393037 & 3394854 & 245.261 & 21.754 & 7.724 & 2.36 & 7.64 & 46 \\
\hline 24 & Puerto Libertad & 26071 & 339102 & 3310543 & 102.690 & 21.032 & 3.309 & 1.01 & 8.99 & 46 \\
\hline 25 & Puerto Peñasco & 26072 & 257413 & 3471016 & 89.478 & 22.051 & 2.792 & 0.85 & 9.15 & $\mathrm{NC}$ \\
\hline 26 & Punta de Agua & 26073 & 562019 & 3145192 & 425.351 & 23.745 & 12.605 & 3.86 & 6.14 & 27 \\
\hline 27 & Quiriego & 26075 & 672845 & 3044717 & 661.968 & 24.131 & 19.395 & 5.93 & 4.07 & 20 \\
\hline 28 & Riíto & 26076 & 132026 & 3561691 & 54.464 & 21.724 & 1.717 & 0.53 & 9.47 & NC \\
\hline 29 & Ruiz Cortines & 26024 & 689796 & 3013561 & 561.978 & 24.817 & 16.141 & 4.94 & 5.06 & NA \\
\hline 30 & Sahuaripa & 26077 & 672011 & 3214637 & 541.820 & 23.306 & 16.268 & 4.98 & 5.02 & 24 \\
\hline 31 & San Bernardo & 26088 & 712586 & 3032407 & 710.917 & 24.391 & 20.672 & 6.33 & 3.67 & NA \\
\hline 32 & Suaqui Grande & 26125 & 608986 & 3141463 & 478.443 & 23.657 & 14.215 & 4.35 & 5.65 & 24 \\
\hline 33 & Tesopaco & 26100 & 660852 & 3079636 & 662.198 & 22.408 & 20.433 & 6.25 & 3.75 & 20 \\
\hline 34 & Tezocoma & 26099 & 677569 & 3059557 & 730.100 & 22.970 & 22.144 & 6.78 & 3.22 & NA \\
\hline 35 & Tres Hermanos & 26102 & 679972 & 3007873 & 571.024 & 25.176 & 16.233 & 4.97 & 5.03 & 24 \\
\hline 36 & Trincheras & 26103 & 448771 & 3363049 & 277.924 & 21.287 & 8.883 & 2.72 & 7.28 & 23 \\
\hline
\end{tabular}

$\mathrm{PP}=$ Precipitation; $\mathrm{T}=$ Temperature; MARI $=$ De Martonne index; HEAI = Hydro-environmental availability index; HEDI = Hydro-environmental drought index; NC= Not for cattle; NA= Data not available. Mean HEAl= 4.2402; Mean HEDI $=5.7598$. 
de acuerdo con los criterios que se indican en el Cuadro 1.

Con la finalidad de corroborar la funcionalidad numérica de IDHA y del ISHA, se aplicaron análisis de regresión y correlación con la pluviometría generada por la información disponible para las 36 localidades evaluadas. Asimismo, se revisaron los coeficientes de agostadero (CAg) (hectáreas por unidad animal (UA), por año) determinados por la Comisión Técnico Consultiva para la Determinación Regional de los Coeficientes de Agostadero (COTECOCA) $(12,13)$ para cada una de las 36 estaciones meteorológicas, se aplicaron análisis de regresión y correlación entre los valores del ISHA y los CAg. Con los datos obtenidos se generaron los mapas de interpolación de la precipitación y de los dos índices mencionados.

\section{RESULTADOS Y DISCUSIÓN}

A partir de la información obtenida de las 36 estaciones meteorológicas del estado de Sonora (Cuadro 2), se observa que los sitios Tesopaco, San Bernardo, Tezocoma y Minas Nuevas son obtained generated interpolation maps of precipitation from the two mentioned indices.

\section{RESULTS AND DISCUSSION}

The information obtained from the 36 weather stations in the State of Sonora (Table 2), shows that sites Tesopaco, San Bernardo, Tezocoma, and Minas Nuevas presented greater rainfall, with annual precipitation (pp) of 757.2, 730.1 662.2 and $710.9 \mathrm{~mm}$, respectively. The driest seasons were Riito, Puerto Peñasco, Puerto Libertad and Pitiquito, with annual values of 54.5, 89.5, 102.7 and $245.3 \mathrm{~mm}$, respectively.

Due to the low pp, water deficiency manifests itself more intensely towards the coast of the Sea of Cortez, exacerbating towards the Northwest of the State (Figure 1a). In contrast, increased water availability is evident towards the mountainous area of the Southeast of the state, shared with the states of Chihuahua and Sinaloa (Figure $1 b$ ).

According to the numerical resolution of the HEAI and HEDI indicators, the stations which

Figura 1. (a) Precipitación anual con datos de 1920 hasta inicios de 2011(9). (b) Índice de disponibilidad hidroambiental (IDHA). (c) Índice de sequía hidro-ambiental (ISHA)

Figure 1. (a) Annual rainfall with data from 1920 until early 2011(9). (b) Hydro-environmental availability index (HEAl).

(c) Hydro-environmental drought index (HEDI)

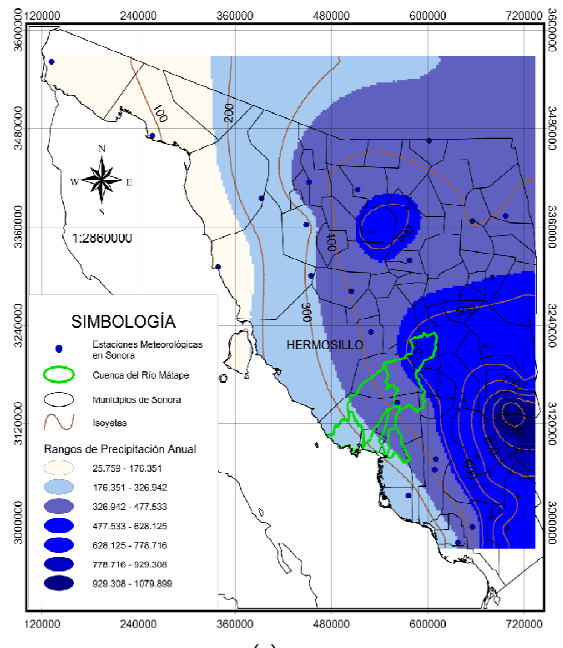

(a)

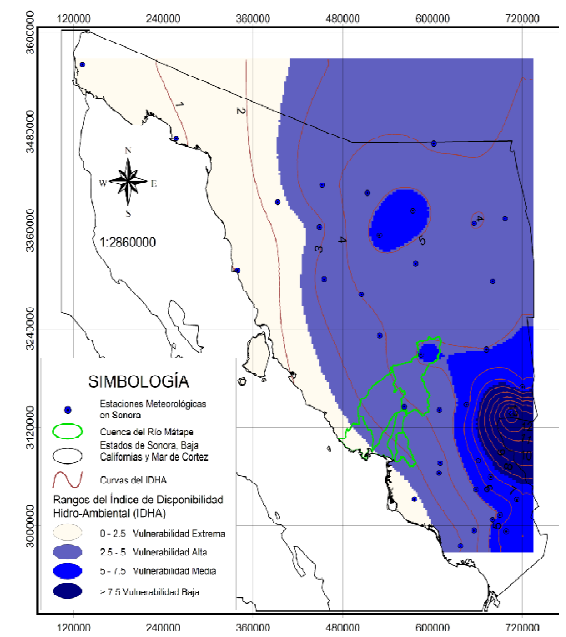

(b)

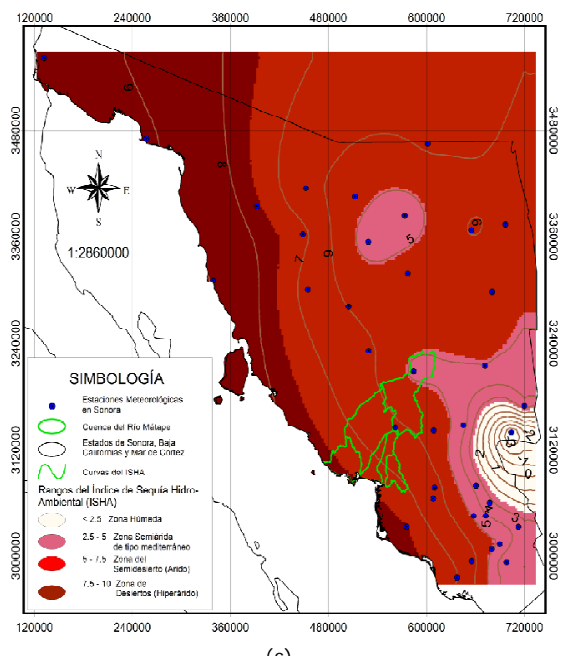

(c) 
las que presentaron mayor pluviosidad, con precipitaciones (pp) anuales de 662.2, 710.9, 730.1 y $757.2 \mathrm{~mm}$, respectivamente. Las estaciones más secas fueron Riíto, Puerto Peñasco, Puerto Libertad y Pitiquito, con valores de $\mathrm{pp}$ anual de 54.5, 89.5, 102.7 y $245.3 \mathrm{~mm}$, respectivamente.

La deficiencia de agua debida a las bajas precipitaciones se manifiesta de manera más intensa hacia la costa del Mar de Cortés, exacerbándose hacia el noroeste del estado (Figura 1a). En contraste, una mayor disponibilidad hídrica se hace evidente hacia la zona montañosa del sureste del Estado, la cual se comparte con los estados de Chihuahua y Sinaloa (Figura 1b).

De acuerdo con la resolución numérica de los indicadores IDHA e ISHA, las localidades que enfrentan una deficiencia hídrica aguda son Riíto, Puerto Peñasco, Puerto Libertad, Pitiquito, estación $4 p 6$ y Trincheras entre otras, cuyos valores de sequía hidro-ambiental se detallan en el Cuadro 2 y en la Figura $1 b$ y c).

Por otro lado, las desviaciones de la media de IDHA e ISHA se muestran en el Cuadro 3. Dichas localidades se ubican en el noroeste de face acute water deficiency were Riito, Puerto Penasco, Puerto Libertad, Pitiquito, station 4p6 and Trincheras, among others, whose drought hydro-environmental values are listed in Table 2 and Figure $1 b$ and $c)$.

On the other hand, deviations from the HEAl and HEDI average are shown in Table 3. These sites are located in the Northwest of Sonora, where the Altar Desert bioclimatic conditions prevail. The station 28 (Riito), is facing the hydro-environmental more severe drought, with HEDI value close to 10, which would be the highest numerical expression of drought.

The dispersion of results estimated for both indicators, related to the 36 weather stations of Table 2, is shown in Figure 2a, and illustrates localities with water deficit and those with water supply availability. It notes that the representative central value for HEDI oscillates around 5.8, while the representative average value for HEAl fluctuates around 4.2. The locality in which HEAl (4.98) and HEDI (5.02) will intersect the values is the number 30 , which corresponds to the 26077 station, in the municipality of Sahuaripa, with $541 \mathrm{~mm}$ of annual average rainfall. According to the trends of both functions, it follows that localities of

Cuadro 3. Coeficientes de agostadero (SRC) para localidades que enfrentan sequía hidro-ambiental severa en Sonora Table 3. Stocking rates coefficients (SRC) for areas facing severe hydro-environmental drought in Sonora

\begin{tabular}{llccccc}
\hline ID & Station & Desv. HEAI mean & Desv. HEDI mean & SRC previous & SRC nwc & SRC ccc \\
\hline 28 & Riíto & -3.7102 & 3.7102 & $\mathrm{NC}$ & $\mathrm{NC}$ & $\mathrm{NC}$ \\
25 & Puerto Peñasco & -3.3902 & 3.3902 & $\mathrm{NC}$ & $\mathrm{NC}$ & $\mathrm{NC}$ \\
24 & Puerto Libertad & -3.2276 & 3.2276 & 46 & 41.1 & 45.3 \\
23 & Pitiquito & -1.8767 & 1.8767 & 46 & 31.2 & 35.4 \\
1 & 4p6 & -1.8384 & 1.8384 & 26 & 31.0 & 35.2 \\
36 & Trincheras & -1.5220 & 1.5220 & 23 & 29.5 & 33.8 \\
13 & Etchojoa & -1.2966 & 1.2966 & 19 & 28.6 & 32.8 \\
14 & Félix Gómez & -0.9177 & 0.9177 & 27 & 27.2 & 31.4 \\
2 & Álvaro Obregón & -0.7262 & 0.7262 & 33 & 26.5 & 30.8 \\
21 & Navojoa & -0.6193 & 0.6193 & 20 & 26.2 & 30.4 \\
\hline
\end{tabular}

$\mathrm{HEAl}=\mathrm{Hydro}-$ environmental availability index; $\mathrm{HEDI}=\mathrm{Hydro-environmental}$ drought index; nwC= Normal wether conditions; $\mathrm{CCC}=$ Climate change conditions; $\mathrm{NC}=$ Not adequate for cattle. 
Sonora, donde prevalecen las condiciones bioclimáticas del desierto de Altar. La localidad 28 (Ríto), es la que enfrenta la sequía hidroambiental más severa, con valor de ISHA cercano a 10, el cual representaría la máxima expresión numérica de la sequía.

La dispersión de los resultados estimados para ambos indicadores, considerando las 36 estaciones meteorológicas del Cuadro 2, se muestra en la Figura 2a, donde se diferencian lower precipitation, need water catchment works such as small or medium dams or other forms of retention. Such constructions are necessary for sustaining cattle in these areas, since moisture from precipitation is insufficient for growth and development of grasslands $(4,12)$.

According to the results obtained by applying the HEAl index (Table 2, Figure 2a), five locations reached values from 0 to 2.5 , representing $13.9 \%$. In these areas, the

Figura 2. (a) Variación de los indicadores IDHA e ISHA, para 36 estaciones meteorológicas de Sonora. (b) Frecuencia de intervalos del IDHA. (c) Regresión entre precipitación normal y coeficientes de agostadero. (d) Regresión entre IDHA y coeficientes de agostadero

Figure 2. (a) Variation of HEAI and HEDI, indicators for 36 weather stations in Sonora. (b) Frequency of intervals of HEAl. (c) Regression between normal precipitation and stocking rates. (d) Regression between HEAl and stocking rates

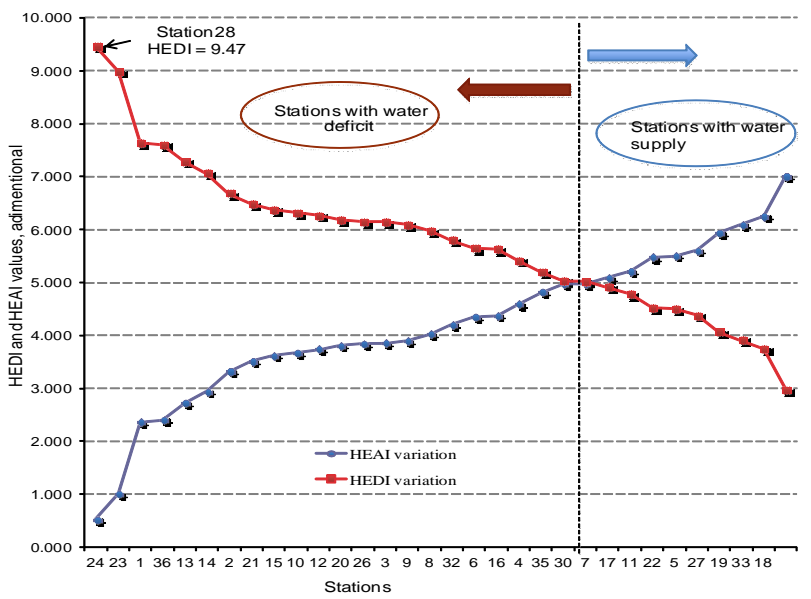

(a)

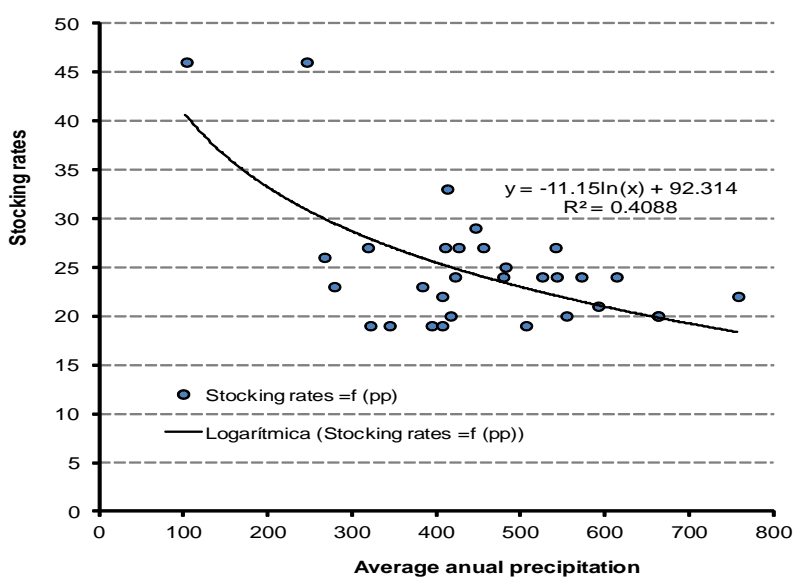

(c)

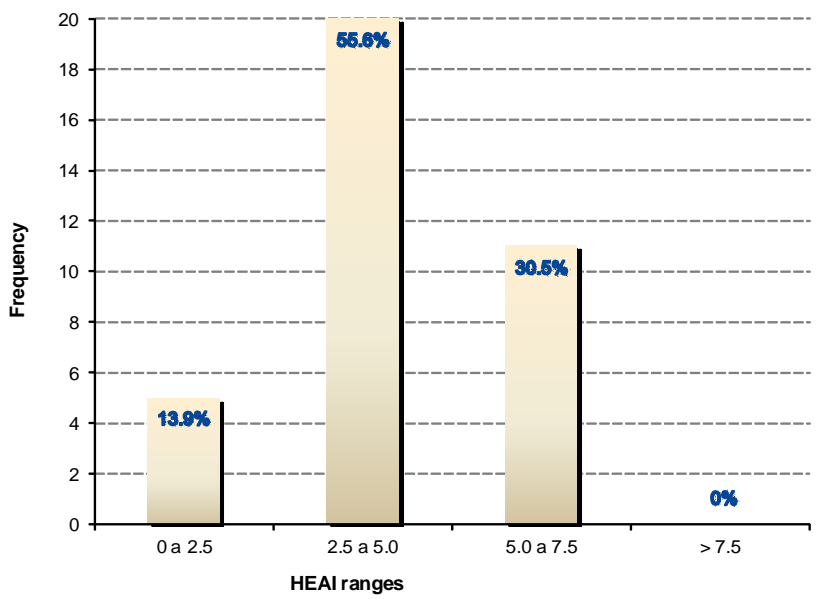

(b)

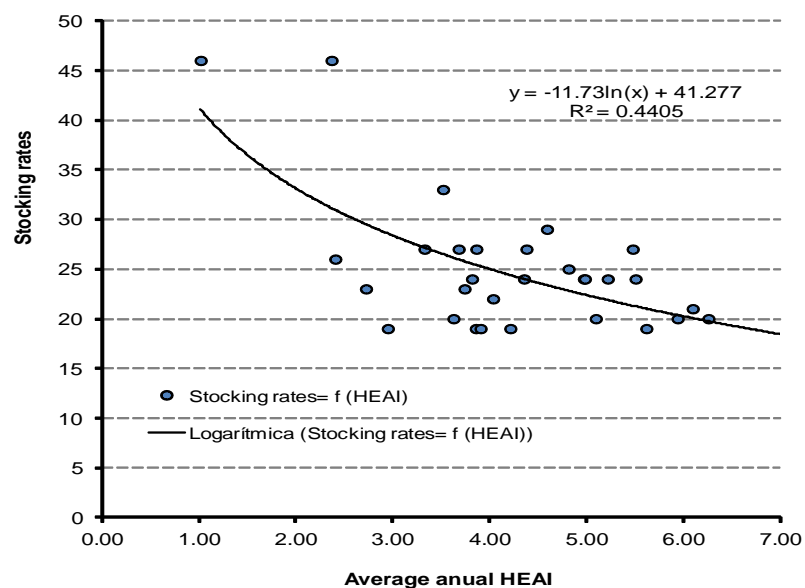

(d) 
de manera ilustrativa las localidades con déficit hídrico de aquéllas con disponibilidad u oferta hídrica. Se observa que el valor central representativo para el ISHA oscila alrededor de 5.8, en tanto que el valor medio representativo para el IDHA fluctúa alrededor de 4.2. La localidad en la cual se interceptan los valores del IDHA (4.98) y el ISHA (5.02) es la número 30, que corresponde a la Estación 26077, en el municipio de Sahuaripa, en la cual se tiene una precipitación promedio anual de $541 \mathrm{~mm}$. De acuerdo a las tendencias de ambas funciones, se infiere que en las localidades con pp menores son necesarias obras de captación de agua como los represos u otras formas de retención de la misma, ya que dichas construcciones son necesarias para el sostenimiento del ganado en estos sitios, toda vez que la humedad proveniente de la precipitación es insuficiente para el crecimiento y desarrollo de los pastizales $(4,12)$.

Según los resultados de aplicación del índice IDHA (Cuadro 2, Figura 2b), cinco localidades presentaron valores de 0 a 2.5 , lo que representa el $13.9 \%$. En dicha superficie los pastizales son altamente vulnerables a las sequias, recomendándose exclusión total para el pastoreo. Por su parte, 20 localidades alcanzaron valores de IDHA que oscilaron de 2.5 a 5 , que constituye el $55.6 \%$, para las que se sugiere manejo con restricciones severas y exclusión total al ganado durante los meses de sequía. Asimismo, once localidades mostraron valores de 5 a 7.5, lo que caracteriza el $30.5 \%$, para las que se propone manejo sostenible con rotaciones adecuadas y prevenciones durante la sequía; por último, ninguna de las localidades analizadas alcanzó valores de la última categoría, IDHA > 7.5 (Figura 2b).

Para el análisis de la relación entre el IDHA y los coeficientes de agostadero (Cuadro 2) se eliminaron cinco estaciones que no cuentan con datos o que COTECOCA considera que no son zonas ganaderas(13): Puerto Peñasco, Riíto, Ruiz Cortines, San Bernardo y Tezocoma. Las dos primeras se clasifican como zonas no ganaderas, grasslands are highly vulnerable to drought, recommending total exclusion for grazing. Meanwhile, 20 stations reached HEAl values ranging from 2.5 to 5.0 , which constitutes about $55.6 \%$, in which management with severe restrictions and total exclusion to livestock is suggested during the dry months. In addition, eleven locations showed values from 5 to 7.5, characterizing $30.5 \%$, for which it can be proposed a sustainable management with appropriate rotations and preventions in the dry season; finally, none of the evaluated locations reached values of the last category, HEAl > 7.5 (Figure 2b).

For the analysis of the relationship between HEAl and stocking rates (Table 2) five stations were eliminated because they do not have data or in some cases, COTECOCA considers it a non-livestock area(13): Puerto Peñasco, Riito, Ruiz Cortines, San Bernardo and Tezocoma. The first two of them are non-livestock areas because they are in the Northwest of the State, in the Altar desert and have very low pp (historical average of 89.5 and $54.5 \mathrm{~mm}$, respectively). In the other three stations, although the pp are high (over 500 to $730 \mathrm{~mm}$ ), COTECOCA $(12,13)$ mentions that these areas are inaccessible to cattle, due to the predominantly irregular and rugged topography (Tables 2,3).

A first approach to the setting of stocking rates was performed using regression analysis with normal values of $\mathrm{pp}$, obtaining the logarithmic model illustrated in Figure $2 c$, with $\mathrm{R}^{2}=0.4088$. To increase the level of adjustment, with data of Table 2 an analysis of regression and correlation between the values of the HEAl and the available values of the SRC, showed that the model explained $44.05 \%$ of the variability observed for the stocking rates in relation to changes in the HEAl. The correlation coefficient was 0.66 , indicating a relationship between both variables; with a confidence interval of $95 \%$, and a probability value of $\mathrm{P}=0.0015$.

The obtained results confirm the significant adjustment estimated by the logarithmic model, 
ya que se encuentran en el noroeste del Estado, en el desierto de Altar y tienen pp muy bajas (promedio histórico de 89.5 y $54.5 \mathrm{~mm}$ de total anual, respectivamente). En las otras tres estaciones, aunque las precipitaciones son altas, de más de 500 a 730 mm, COTECOCA) $(12,13)$ menciona que son zonas donde los terrenos son inaccesibles para el ganado, debido a la topografía irregular y accidentada predominante en dichas localidades (Cuadros 2, 3).

Una primera aproximación al ajuste de los coeficientes de agostadero se realizó mediante análisis de regresión con los valores normales de pp, del cual se obtuvo el modelo logarítmico que se ilustra en la Figura $2 c$, con $\mathrm{R}^{2}=0.4088$. Para incrementar el nivel de ajuste, con los datos del Cuadro 2 se realizó un análisis de regresión y correlación entre los valores obtenidos del IDHA y los valores disponibles de los coeficientes de agostadero (Figura 2d). El estadístico $\mathrm{R}^{2}$ indicó que el modelo explica $44.05 \%$ de la variabilidad observada para los coeficientes de agostadero en relación a los cambios en el IDHA. Por su parte, el coeficiente de correlación fue igual a 0.66 , indicando una relación suficiente entre ambas variables; con un intervalo de confianza de $95 \%$, toda vez que el valor de probabilidad fue de $\mathrm{P}=0.0015$.

Los resultados obtenidos confirman el ajuste significativo estimado por el modelo logarítmico, que describe la relación numérica entre los coeficientes de agostadero y el IDHA. Del anterior procedimiento se generó la ecuación del modelo obtenido para el análisis de localidades en condiciones de clima normal (ccn), el cual se representa mediante la siguiente expresión (Ecuación 3):

Coeficiente de agostadero $\mathrm{ccn}=$

$-11.73 \ln ($ IDHA $)+41.277$

En virtud de que la desviación absoluta promedio de los coeficientes de agostadero en relación con la media fue de 4.3 ha, para la aplicación del modelo obtenido en condiciones de cambio climático (que en la zona de estudio se espera cause sequías más intensas y más which describes the numerical relationship between SRC and the HEAl. The following expression represents the equation model (Equation 3) obtained for the analysis of localities with normal weather conditions (nwc).

Stocking rate $n w c=-11.73 \ln (\mathrm{HEAl})+41.277 \ldots \ldots . . .(3)$

Since the absolute average deviation of the stocking rates in relation to the mean was 4.3 ha, for the application of the model obtained under conditions of climate change (which in the study area expects to cause more intense and more prolonged droughts), this deviation was included in the subsequent analysis. The equation of the model for determining the SRC under climate change conditions (ccc), is represented by the following expression (Equation 4):

Stocking rate $\mathrm{ccc}=-11.73 \ln (\mathrm{HEAl})+45.5$

The values set for the rangeland in normal conditions averaged 24.8 ha $\mathrm{AU}^{-1}$, which increased to 29.1 ha for the climate change conditions. The stocking rate coefficients estimated for both conditions (SR nwc and SR ccc are shown in Table 3).

Regional agricultural production systems have been subjected for decades to a series of paternalistic policies and with little or no participation of the social grassroots in development planning $(1,2)$. This, coupled with a poor management application and land-use programs, exacerbates the fragility of such ecosystems and mainly in the rangelands; dynamic ecosystems, able to reach states of equilibrium where grazing and conservation are compatible, or conversely, reach degraded states as a result of overgrazing(14). In this sense, in different forums has been debated and confirmed that to halt and reverse soil degradation in the watershed of arid rangelands, the causing factors should be excluded and also it is relevant to modify the use and management according to its productive potential(15). Some authors(16) pointed out that in addition to the water shortage and water deficit, the livestock problem is accentuated by 
prolongadas), dicha desviación se consideró en el análisis subsecuente. La ecuación del modelo para la determinación del coeficiente de agostadero en condiciones de cambio climático (ccc), se representa mediante la siguiente expresión (Ecuación 4):

Coeficiente de agostadero $\mathrm{ccc}=$ $-11.73 \ln (\mathrm{IDHA})+45.5$

El promedio de los valores ajustados para el coeficiente de agostadero en condiciones normales fue de $24.8 \mathrm{ha} / \mathrm{UA}$, el cual se incrementó a 29.1 ha/UA, para las condiciones de cambio climático. Los coeficientes de agostadero estimados para ambas condiciones (CAg ccn y CAg ccc) se muestran en el Cuadro 3.

Los sistemas regionales de producción agropecuarios han estado sometidos durante décadas a una serie de políticas paternalistas y con poca o nula participación de la base social en la planificación del desarrollo(1,2). Lo anterior, aunado a una escasa aplicación de programas de manejo y ordenamiento, exacerba la fragilidad de este tipo de ecosistemas y principalmente en los agostaderos, que son ecosistemas dinámicos, capaces de alcanzar estados de equilibrio donde es compatible la explotación y la conservación o, por el contrario, alcanzar estados degradados a consecuencia del excesivo pastoreo(14). En este sentido, en diversos foros se ha debatido y confirmado que para detener y revertir la degradación de los suelos en los agostaderos de cuencas de zonas áridas deben excluirse los factores causantes y modificar su uso y manejo conforme a su potencial productivo(15). Se ha mencionado(16) que además del desabasto de agua y deficiencia hídrica, el problema ganadero es acentuado por la distribución inadecuada del ganado que provoca sobrecarga de los agostaderos y deterioro del potencial forrajero.

Para valorar la condición hidrológica del agostadero y pronosticar eficazmente las sequias, existen métodos como el Índice de Palmer ${ }^{(9)}$ y otros, aunque demandan una amplia the inadequate distribution of livestock triggering overgrazing and herbage potential deterioration.

To assess the hydrologic condition of the rangeland and effectively predict droughts, there are methods like the Palmer Index(9), and others, although they require a wide range of climatic variables, not always available for analysts. The modification of De Martonne to HEAI Index shows a better numerical trend associated and correlated to the increases of humidity generated by precipitation, while the supplementary indicator, HEDI, is a tool to differentiate locations and times, with respect to the consequent hydrological deficiency due to an abnormally low and scarce rainfall(10). The advantage of the proposed model is the possibility of updating it in terms of climate change.

The precipitation distribution in Sonora is typical of arid and semi-arid areas, insufficient and irregular in its distribution throughout the year. The $\mathrm{pp}$ that occurs in the summer-autumn period represents $88 \%$ of the total and the winter-spring around $12 \%(11)$. According to COTECOCA, the pp rating was the classification of the last forty years with records of the "Water National Commission" (CONAGUA, acronyms in Spanish) Sonora, on the basis of a mean annual rainfall of $366.2 \mathrm{~mm}$, obtained with the records for the period 1968 to $2007(13,16,17)$. This classification shows the occurrence of droughts in six of the past $40 \mathrm{yr}$ (Table 4). There are 14 $\mathrm{yr}$ that presented pp less than normal for the area (4), whose analysis is complicated by anomalous precipitation patterns that seems to be influenced by complex thermodynamic interactions between the orography and regional circulation of the monsoon(18).

The number of cattle lost by drought in 2011 reached 33,300 heads, what is considered a normal mortality per year, that is, $2 \%$ of the cattle herd of Sonora(17). In February, 2012 SAGARPA stated that 600,000 heads are at risk due to lack of water in the State; in this regard, technical difficulties still prevail for predicting 
gama de variables climáticas, no siempre disponibles para los analistas. La modificación del índice de De Martonne a IDHA, muestra una tendencia numérica mejor asociada y correlacionada a los incrementos de la humedad ambiental generada por la precipitación, en tanto que el indicador complementario, el ISHA, constituye una herramienta para diferenciar localidades y épocas, con respecto a la deficiencia hidrológica consecuente de pp anormalmente bajas y escasas(10). La ventaja del modelo propuesto es la posibilidad de actualizarlo en condiciones de cambio climático.

La distribución de la precipitación en Sonora es típica de las zonas áridas y semiáridas, escasas e irregulares a lo largo del año. La pp que ocurre en el período verano-otoño representa $88 \%$ del total y la de invierno-primavera alrededor del $12 \%$ (11). Conforme a los criterios establecidos por COTECOCA, para valorar las pp se realizó la clasificación de los últimos cuarenta años con los registros de la Comisión Nacional del Agua (CONAGUA), Delegación Sonora, tomando como base una precipitación media anual de $366.2 \mathrm{~mm}$, obtenida con los registros del periodo 1968 al 2007(13,16,17). Dicha clasificación se muestra en el Cuadro 4, donde se observa la ocurrencia de sequías en seis de los últimos 40 años. En dicho periodo se detectan 14 años en que se presentaron pp menores a las normales para la zona(4), cuyo análisis se complica por los patrones anómalos en la precipitación que parecen estar influidos por interacciones termodinámicas complejas entre la orografía y la circulación regional del monzón(18).

La cantidad de ganado muerto por la sequía en el 2011 ascendió a 33,300 cabezas, lo que se considera mortandad normal por año, esto es, $2 \%$ del hato ganadero de Sonora(17). En febrero del 2012 SAGARPA señaló que 600 mil cabezas de ganado están en riesgo debido a la falta de agua en la entidad; al respecto, aún prevalecen dificultades técnicas para predecir la mortandad del ganado en función de la condición de los pastizales y para ajustar de
Cuadro 4. Calificación de las sequías para el estado de Sonora en los últimos 40 años según precipitaciones, considerando precipitación media anual de $366.2 \mathrm{~mm}$

Table 4. Qualification of droughts for the State of Sonora in the past 40 years according to rainfall, considering annual average precipitation of $366.2 \mathrm{~mm}$

\begin{tabular}{lcc}
\hline $\begin{array}{l}\text { Number } \\
\text { of years }\end{array}$ & Qualification & $\begin{array}{c}\text { Accumulated number } \\
\text { of dry years }\end{array}$ \\
\hline 1 & Good & \\
8 & Very good & \\
17 & Normal & \\
3 & Dry & 14 \\
5 & Very dry & 11 \\
6 & Drought & 6 \\
40 & & 14 \\
\hline
\end{tabular}

Source: CONAGUA data with registers form 1968 to 2007. Adapted from López-Reyes et al.(2)

the livestock mortality depending on the condition of grasslands and to adjust in a timely manner the stocking rates. The field methodology employed by COTECOCA is very demanding of man-hours and requires a continuous effort(13). The theoretical framework based on this methodology is related to the climax vegetation or balance. I.e. each vegetation type and in particular each herbage productivity site is a plant community in equilibrium, which is the result of a plant succession. Because of this, there is a need to reckon for methods and appropriate infrastructure that are applied promptly in case of hydro-dimatic contingencies $(1,12,16)$. To mitigate the effects of drought in Sonora, during 2012, the Government allocated resources by 50 million pesos. The Regional Livestock Union of Sonora (UGRS) disposed of 38.1 million pesos approved by the Federal Government to address the problem of drought, which caused shortages of water and grass in rangelands(17). However, such support is granted without the application of quantitative criteria, so existing diagnostic tools could optimize it. Several studies on the impact of the drought on livestock have generated recommendations to mitigate the effects of the phenomenon. The practices 
manera oportuna los coeficientes de agostadero. La metodología de campo empleada por COTECOCA es muy demandante de horashombre y requiere de un esfuerzo continuo(13). El marco teórico en el que se basa dicha metodología es el de la vegetación clímax o de equilibrio. Es decir, cada tipo de vegetación y en particular cada sitio de productividad forrajera es una comunidad vegetal en equilibrio, que es el resultado de una sucesión vegetal. Por lo anterior, es evidente la necesidad de métodos y en su caso de infraestructura, que se apliquen de manera expedita en caso de contingencias hidroclimáticas $(1,12,16)$. Para mitigar los efectos de la sequía durante 2012 en Sonora, SAGARPA destinó recursos por 50 millones de pesos. La Unión Ganadera Regional de Sonora (UGRS) dispuso de 38.1 millones de pesos autorizados por el Gobierno Federal para atender el problema de sequía, que causó escasez de agua y pasto en los agostaderos(17). No obstante el esfuerzo, dichos apoyos se otorgan sin la aplicación de criterios cuantitativos, por lo que pudieran optimizarse de existir herramientas de diagnóstico. Diversos estudios sobre el impacto de la sequía en la ganadería han generado recomendaciones para mitigar los efectos del fenómeno. Las prácticas necesarias para enfrentar la sequía se basan en la búsqueda del equilibrio entre la disponibilidad de forraje y la carga animal(4).

\section{CONCLUSIONES E IMPLICACIONES}

Según los resultados obtenidos, el índice de aridez de De Martonne muestra suficiente sensibilidad a las características climáticas de Sonora, variando de manera directamente proporcional con la precipitación. Los índices IDHA e ISHA que se derivan del primero mencionado, muestran una elevada sensibilidad en correspondencia con la distribución espacial de la vegetación de pastizales y presentan una estrecha relación con los coeficientes de agostadero. Mediante dichas herramientas numéricas se puede proponer la carga animal según la estimación de las variaciones u oscilaciones de la precipitación y la temperatura needed to face the drought are based on the search for the balance between the availability of fodder and stocking rates(4).

\section{CONCLUSIONS AND IMPLICATIONS}

The aridity index of De Martonne shows sufficient sensitivity to the climatic characteristics of Sonora, varying directly proportionally with precipitation. HEAl and HEDI, which were derived from the first one, are closely related to the stocking rates and show a high sensitivity in correspondence with the spatial vegetation distribution in grasslands. Through these numerical tools, grazing capacity could be established according to the estimation of the rainfall variations and temperature fluctuations in the State, and its application on precipitation deficiency conditions and climate change scenarios being feasible.

\section{ACKNOWLEDGMENTS}

This work was supported by the Sectorial Fund for basic research SEP-CONACyT, through the project "Determination and construction of indicators of the water footprint and desertification as a result of agricultural overexploitation and climate change" (0134460), with internal code 180 c. The authors are grateful to the staff of the technical area of the CONAGUA in Hermosillo, Sonora, for data provided and the thematic network of disasters associated with hydro meteorological phenomena and climate of CONACYT (REDESClim) for partial support of this research. Particular thanks to Lic. Omar Acosta Fajardo for his guidance and support for databases maintenance, and geographic information systems.

End of english version

en el Estado, siendo factible su aplicación en condiciones de deficiencia pluviométrica y en escenarios de cambio climático. 


\section{AGRADECIMIENTOS}

El presente trabajo fue financiado por el Fondo Sectorial para la Investigación básica CONACyTSEP, mediante el Proyecto "Determinación y construcción de indicadores de la huella hídrica y desertificación como consecuencia de la sobreexplotación agropecuaria y del cambio climático" (0134460), con clave interna 180C. Los autores agradecen al personal del Área Técnica de la CONAGUA en Hermosillo, Sonora, por los datos proporcionados y a la Red Temática de Desastres Asociados a Fenómenos Hidrometeorológicos y Climáticos de CONACYT (REDESClim) por apoyo parcial a esta investigación. Particular agradecimiento al Lic. Omar Acosta Fajardo por su orientación y apoyo en sistemas de información geográfica y mantenimiento de bases de datos.

\section{LITERATURA CITADA}

1. Gil SB, Herrero MA, Flores MC, Pachoud ML, Hellmers MM. Intensificación agropecuaria evaluada por indicadores de sustentabilidad ambiental. Arch Zootec 2009;58(223):413423.

2. Torres-Lima PA, Martínez-Cano AG, Portes-Vargas L, Rodríguez-Sánchez LM, Cruz-Castillo JG. Construcción local de indicadores de sustentabilidad regional. Un estudio de caso en el semidesierto del noreste de México. Región y Sociedad 2008;20(43):25-60.

3. Caire G. El manejo integrado de cuencas como instrumento para el desarrollo regional. En: Abardía A, Morales $F$ (coordinadores). Desarrollo regional - Reflexiones para la gestión de los territorios. Alternativas y Capacidades, A.C. Primera ed. Ciudad de México: MC editores; 2008: 187-213.

4. López-Reyes M, Solís-Garza G, Murrieta-Saldíva J, LópezEstudillo R. Percepción de los ganaderos respecto a la sequía. Viabilidad de un manejo de los agostaderos que prevenga sus efectos negativos. Estudios Sociales 2010; XVII (Núm. Esp.): 221-242.

5. Hanselka CW, Kilgore DE. The Nueces River Valley: The cradle of the Western livestock industry. Rangelands 1987; 9(5): 195-198.
6. Lok S, Crespo G, Torres V. Metodología para la selección de indicadores de sostenibilidad del sistema suelo-planta en pastizales. Rev Cubana Cienc Agr 2008;42(1):71-76.

7. DOF. 2001. Norma Oficial Mexicana NOM-020-RECNAT-2001. Subsecretaría de Fomento y Normatividad Ambiental de la Secretaría de Medio Ambiente y Recursos Naturales (SEMARNAT). México, DF. Diciembre 10, 2001.

8. Crespo-Pichardo G. Comparación de dos metodologías para el cálculo del índice de severidad de sequía para doce reservas de la biosfera mexicana. Reporte final al Programa MAB-UNESCO 2004; [en línea]: http://portal.unesco.org/ science/en/ev.php-URL_ID=7087\&URL_DO= DO TOPIC\& URL_SECTION=201.html. Consultado 5 Sep, $201 \overline{2}$.

9. Palmer WC. Meteorological Drought. U.S. Dep. Commerce. Weather Bureau Res. Paper 45. USA: 1965.

10. Mercado-Mancera G, Troyo-Diéguez E, Aguirre-Gómez A, Murillo-Amador B, Beltrán-Morales LF, García-Hernández J L. Calibración y aplicación del índice de aridez de De Martonne para el análisis del déficit hídrico como estimador de la aridez y desertificación en zonas áridas. Universidad y Ciencia 2010;26(1):51-64.

11. WMO. World Meteorological Organization, CLImate COMputing Project. 2012. [on line]: http://www.wmo.ch/ pages/prog/wcp/wcdmp/clicom/indexen.html. Accessed March 20, 2012.

12. Comisión Técnico Consultiva para la Determinación Regional de los Coeficientes de Agostadero (COTECOCA). Tipos de vegetación en el Edo. de Sonora con diferenciación de sitios de productividad forrajera. Escala 1:500,000. COTECOCA, SARH, México. 1986.

13. Comisión Técnico Consultiva para la Determinación Regional de los Coeficientes de Agostadero (COTECOCA). Coeficientes de agostadero de la República Mexicana, Estado de Sonora. COTECOCA, SARH, México. 1989.

14. Rebollo S, Gómez-Sal A. 2003. Aprovechamiento sostenible de los pastizales. Ecosistemas 2003/3. [en línea]: http:// www. aeet. org/ecosistemas/033/investigacion7. htm. Consultado: 25 Jul, 2012.

15. Márquez-Madrid M, Ruiz-Garduño RR, Valdez-Cepeda RD, Blanco-Macías F, Pérez-Pérez VG. Estado de degradación del suelo en los pastizales de la cuenca del Río Juchipila. Simp Inter Pastizales. UANL - ITESM. 2009:16-27.

16. Anaya-Nevárez $E$, Barral $H$. La ganadería y su manejo en relación con los recursos agua y pastizal en la zona semiárida de México. Folleto Científico No 5. INIFAP-ORSWM. CENID-RASPA. Gómez Palacio, Dgo. 1995.

17. Navarro-Córdova A. Situación actual de los agostaderos en Sonora. Efecto del manejo y cambio climático. Informe de estudio. SAGARPA, SAGARHPA, CTEE. Hermosillo, Son. 2012.

18. Brito-Castillo L, Vivoni ER, Gochis DJ, Filonov A, Tereshchenko I, Monzon C. An anomaly in the occurrence of the month of maximum precipitation distribution in northwest Mexico. J Arid Environ 2010;74(2010):531-539. 